
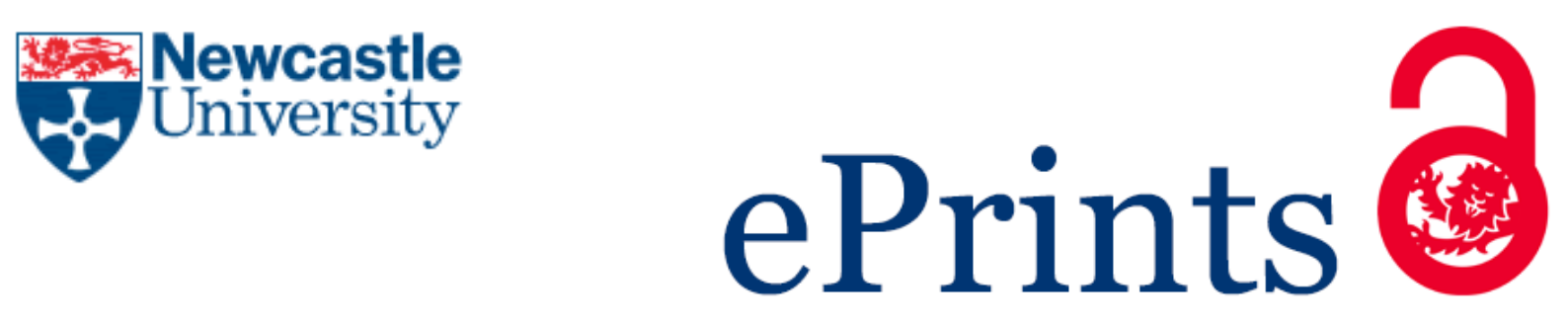

Wei J, Zhao S, Ji L, Zhou T, Miao Y, Scott K, Li D, Yang J, Wu X.

Reuse of Ni-Co-Mn oxides from spent Li-ion batteries to prepare

bifunctional air electrodes.

Resources, Conservation and Recycling 2018, 129, 135-142.

\title{
Copyright:
}

(C) 2018. This manuscript version is made available under the CC-BY-NC-ND 4.0 license

DOI link to article:

https://doi.org/10.1016/j.resconrec.2017.10.021

Date deposited:

$18 / 01 / 2018$

Embargo release date:

06 November 2018

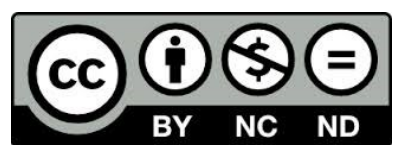

This work is licensed under a

Creative Commons Attribution-NonCommercial-NoDerivatives 4.0 International licence 


\section{Reuse of Ni-Co-Mn oxides from spent Li-ion batteries to prepare bifunctional air electrodes}

Jucai Wei ${ }^{1}$, Shichang Zhao ${ }^{1}$, Liangxin $\mathrm{Ji}^{1}$, Ting Zhou ${ }^{1}$, Yangyang Miao ${ }^{1}$, Dinggen $\mathrm{Li}^{2}$, Keith $\mathrm{Scott}^{3, *}, \mathrm{Xu} \mathrm{Wu}{ }^{1, *}$

1, School of Environmental Science and Engineering, Huazhong University of Science and Technology, Wuhan 430074, China;

2, School of Energy and Power Engineering, Huazhong University of Science and Technology, Wuhan 430074, China;

3, School of Chemical Engineering and Advanced Materials, Newcastle University, Newcastle upon Tyne, NE1 7RU, United Kingdom;

\section{Abstract}

Spent lithium ion batteries (SLIB) are potential environmental hazards and if not recycled waste natural resources. We demonstrate for the first time a process to directly reuse Ni-Co-Mn oxides from SLIBs to prepare air electrodes based on a simple thermal treatment method. The effects of heating temperature and duration on the properties of Ni-Co-Mn oxides using scanning electron microscopy and X-ray diffraction is described. The Ni-Co-Mn oxide materials were found to be mainly $\mathrm{LiNi}_{1-\mathrm{x}-\mathrm{y}} \mathrm{Co}_{\mathrm{x}} \mathrm{Mn}_{\mathrm{y}} \mathrm{O}_{2}$, with the $\alpha-\mathrm{NaFeO}_{2}$-type structure (PDF file: 01-075-9200). After heat treatment at $600^{\circ} \mathrm{C}$, the Ni-Co-Mn oxides exhibited the spinel structure (PDF file: 00-048-0261). Electrochemical tests revealed that the Ni-Co-Mn oxides heat-treated at $600^{\circ} \mathrm{C}$ for 300 minutes, exhibited remarkable bifunctional catalytic activities towards the oxygen evolution and oxygen reduction reactions in aqueous $\mathrm{KOH}$ electrolyte. The electron transfer number on $\mathrm{Ni}-\mathrm{Co}-\mathrm{Mn}$ oxide electrode for oxygen reduction was about 3.6. When these Ni-Co-Mn oxide powders were applied in an air battery, the energy efficiency was $75 \%$ at a current density of $10 \mathrm{~mA} \mathrm{~cm}^{-2}$, at room temperature.

\section{Keywords:}

Recycling, spent lithium ion battery; Ni-Co-Mn oxides; bifunctional air electrode; oxygen reduction reaction; oxygen evolution reaction; metal air battery; alkaline fuel cells;

\footnotetext{
* Corresponding author: Prof Xu Wu, Telephone: +86 27 87792040; E-mail address: 2015010008@hust.edu.cn; Address: Room Bei209, Dong16 Building, Huazhong University of Science and Technology,
} 


\section{Introduction}

The amount of spent lithium ion batteries (SLIBs) is growing rapidly and according to the data published by Nation Bureau of Statistics of the People's Republic of China ${ }^{1}$, in the first half of 2016, lithium ion battery production reached 2.98 billion units. In addition there is a predicted growth rate of $20.7 \%$, due mainly to the quantity of mobile phones produced reaching 0.97 billion, with a growth rate of $23.3 \%$. This amount is set to increase dramatically in the near future, due to the large numbers of electric automobiles that are likely to adopt lithium ion batteries. In 2016, the quantity of electric automobiles already reached 2.85 million in China, with a growth rate of 88.7\%. SLIBs are important environmental pollutants, which often contain some reactive materials that can explode at high temperature, such as organic solvents and carbon powders, and harmful heavy metal ( $\mathrm{Ni}, \mathrm{Co}, \mathrm{Mn}, \mathrm{Cu}$, etc.) compounds that can pollute water and soil ${ }^{2}$. Nonferrous metal materials are the major components in SLIBs, with for example, the positive electrode of a lithium ion battery containing between 5$20 \mathrm{wt} . \%$ cobalt $^{3}$, a percentage much higher than that of cobalt concentrates from mines ${ }^{4}$. In order to avoid environmental problems and to effectively recover these valuable nonferrous metal resources, it is necessary to improve SLIB recycling techniques ${ }^{2,5}$. Typical recycling methods for SLIBs involve lengthy and intricate procedures, some of which even cause secondary pollution, making the recycling cost high and restricting the economic drivers for SLIBs collection and recycling ${ }^{2,3}$. Currently in China, only about $2 \%$ of SLIBs are recycled and most are treated by landfilling ${ }^{4,6,7}$. It is thus highly desirable to develop clean, low-cost and efficient recycling methods for SLIBs, by for example, attempting to directly reuse the electrode materials from SLIBs to prepare new batteries or some other electrochemical energy devices.

Lithium ion batteries mainly consist of the positive electrodes (metal oxides powders coated on aluminum foil), the negative electrodes (carbon powders coated on copper foil), polymer binders, electrolytes, and separators. The metal oxides in positive electrodes could be $\mathrm{LiCoO}_{2}, \mathrm{LiMn}_{2} \mathrm{O}_{4}, \mathrm{LiNi}_{1-\mathrm{x}-\mathrm{y}} \mathrm{Co}_{\mathrm{x}} \mathrm{Mn}_{\mathrm{y}} \mathrm{O}_{2}, \mathrm{LiFePO}_{4}$, etc., depending on the styles and applications of lithium ion batteries ${ }^{8-13}$. Such oxides materials can have one of three structure types: an ordered rock salt-type structure, a spinel-type structure, or an olivine-type structure ${ }^{10}$. A laboratory-scale lithium-ion battery recycling process was developed by Scrosati ${ }^{14}$, based on simple and environmentally 
compatible operations, to prepare lithium cobalt oxide electrodes from recycled Lithium ion batteries. $\mathrm{Ra}^{15}$ recovered and renovated $\mathrm{LiCoO}_{2}$ from spent lithium ion batteries and proved its battery performance was quite promising. Garcia et al. showed that cobalt recycling from lithium ion batteries was economic and environmentally viable for application in supercapacitor devices ${ }^{16}$ and solid oxide fuel cell ${ }^{17}$. Liu ${ }^{18,19}$ reused and treated $\mathrm{LiCoO}_{2}$ from SLIBs, using a thermal method, and showed that these materials exhibited excellent electrochemical activity.

The oxides of transition metals, including $\mathrm{Co}_{3} \mathrm{O}_{4}, \mathrm{NiO}, \mathrm{MnO}_{\mathrm{x}}, \mathrm{Fe}_{2} \mathrm{O}_{3}, \mathrm{CuO}, \mathrm{V}_{2} \mathrm{O}_{5}$, $\mathrm{MoO}_{3}$ and $\mathrm{Y}_{2} \mathrm{O}_{3}$ have also been extensively studied as catalysts for air electrodes ${ }^{20-22}$. Notably, it has been reported that Li-doped $\mathrm{Co}_{3} \mathrm{O}_{4}$ spinel nanopowders exhibited good catalytic activity for both the oxygen reduction reaction (ORR) and the oxygen evolution reaction (OER), and thus may find applications in metal air batteries and alkaline fuel cells ${ }^{23-26}$. Therefore, we propose a new approach to reuse metal oxides from SLIBs, in the preparation of bifunctional air electrodes. In this study, some spent Ni-Co-Mn ternary lithium ion batteries (cylindrical 18650 style) were provided by Tianneng Battery Group Co., Ltd (also known as TN powder, one of the largest electrical bike manufacturers in China) as typical samples for the recycling study. This paper reports the preliminary results on the electrochemical activity of such air electrodes and there use in a metal air battery to examine the feasibility of this approach for SLIBs recycling.

Following the feasibility of this idea an over-riding question that will need to be considered is that of re-using lithium ion batteries produced by different manufacturers, and for different application purposes, that will have various types of metal oxides, in terms of crystallite structures, element compositions and different additives in electrodes. The lithium ion, binders, carbon materials, and electrolyte in the metal oxide materials recycled from SLIBs could also influence the properties of recycled metal oxides. 


\section{Experimental}

\subsection{Ni-Co-Mn metal oxides recovery from SLIBs}

All reagents in this study were analytical grade and reagent solutions were prepared with deionized water $\left(18.3 \mathrm{M} \Omega \mathrm{cm}^{-2}\right)$. In the recovery procedure, shown in Figure 1, the cylindrical SLIBs were first discharged thoroughly by a battery testing system (Neware, China) to prevent the risk of self-ignition and then subsequently dismantled manually. Once dismantled, the anodes (coatings on copper foils) and cathodes (coatings on aluminum foils) were manually uncurled and separated. The cathodes were cut into small pieces and immersed in $10 \mathrm{wt} . \% \mathrm{NaOH}$ solution at $60^{\circ} \mathrm{C}$ for $15 \mathrm{~min}$, to dissolve the aluminum foil by reactions with $\mathrm{NaOH}$. The black coatings remaining in the $\mathrm{NaOH}$ solutions were collected and washed with deionized water several times, before being dried at $105{ }^{\circ} \mathrm{C}$, for 12 hours. Samples of the recycled cathode materials were heat-treated at different temperatures of 300,600 and $900{ }^{\circ} \mathrm{C}$ for durations between 60 to 420 minutes in a furnace, and then left to cool naturally to room temperature.

Figure. 1 Illustration of treatment of spent Lithium ion batteries.

\subsection{Characterizations}

The cathode materials and Ni-Co-Mn oxides were characterised by X-ray fluorescence (XRF, PANalytical Zetium), X-ray diffraction (XRD, Haoyuan DX-27mini), Thermogravimetric analysis (TA, Waters SDTQ600), scanning electron microscopy (SEM, Hitachi TM3030), and by electrical resistivity (Rooko FT-300I).

\subsection{Electrode preparation and electrochemical measurements}

Electrochemical experiments were carried out with an electrochemical workstation (CorrTest CS310), using a three-electrode cell with $1 \mathrm{~mol} \mathrm{dm}^{-3}$ (M) KOH electrolyte, a Pt wire counter electrode, and a $\mathrm{Ag} / \mathrm{AgCl}$ reference electrode $(+0.197 \mathrm{~V}$ vs. normal hydrogen electrode, NHE at $25{ }^{\circ} \mathrm{C}$ ). All potentials are presented vs. this $\mathrm{Ag} / \mathrm{AgCl}$ electrode, unless otherwise specified. Suspensions of Ni-Co-Mn oxides powders were prepared by adding $75 \mathrm{mg}$ of the sample powder into $3 \mathrm{~cm}^{3}$ of $6.68 \mathrm{wt} . \%$ Nafion solution in ethanol. The suspension "ink" was prepared by uniformly dispersing the oxide powders by ultrasonication and shaking overnight. The working electrode was prepared by dropping 2.5 microlitres $(\mu \mathrm{L})$ of suspensions on the glassy carbon rotating 
disc electrode (geometric area $0.125 \mathrm{~cm}^{2}$ ) with a micropipette and drying at $60{ }^{\circ} \mathrm{C}$ for 5 $\min$.

The ORR activities of Ni-Co-Mn oxides were evaluated using the rotating disc electrode and linear sweep voltammetry (LSV) in an $\mathrm{O}_{2}$-saturated $1 \mathrm{~mol} \mathrm{dm}{ }^{-3} \mathrm{KOH}$ electrolyte, with a scan rate of $10 \mathrm{mV} \mathrm{s}^{-1}$, at room temperature. The OER activities of Ni-Co-Mn oxides were evaluated with a rotating disc electrode linear sweep voltammetry (LSV) in a $\mathrm{N}_{2}$ atmosphere $1 \mathrm{~mol} \mathrm{dm}^{-3} \mathrm{KOH}$ electrolyte at a scan rate of $0.5 \mathrm{mV} \mathrm{s}^{-1}$ at $30{ }^{\circ} \mathrm{C}$. Electrochemical measurements were performed with an electrochemical workstation (IviumStat. h).

The number of electrons transferred during ORR was obtained using the following equation:

$$
\mathrm{n}=\frac{4 I_{d}}{I_{d}+I_{r} /_{N}}
$$

where $I_{d}, I_{r}$, and $N$ represent the disk current, ring current, and the current collection efficiency of the electrode (0.37), respectively $y^{27,28}$.

For the zinc-air battery testing, polarization curves were measured using a electrochemical workstation (IviumStat. h). The cathode ink was prepared by ultrasonically mixing $150 \mathrm{mg}$ Ni-Co-Mn oxides that had been heated at $600^{\circ} \mathrm{C}$ for 300 min, with $150 \mathrm{mg}$ carbon powders (XC-72R), $9.75 \mu \mathrm{L} 60 \mathrm{wt} . \%$ polytetrafluoroethylene (PTFE) suspension and $5 \mathrm{~mL}$ of $6.67 \mathrm{wt} \%$ Nafion ethanol solution. The resultant solution was dispersed uniformly by stirring and sprayed onto the gas diffusion layer. A two electrode battery configuration was created by pairing Ni-Co-Mn oxides loaded on a carbon paper electrode $\left(2 \mathrm{~cm}^{2}\right.$, catalyst loading $4 \mathrm{mg}$ ) with a pure $\mathrm{Zn}$ foil (area of $2 \mathrm{~cm}^{2}$, and thickness of $0.3 \mathrm{~mm}$ ) in $6 \mathrm{~mol} \mathrm{~L}^{-1} \mathrm{KOH}+0.2 \mathrm{~mol} \mathrm{~L}^{-1}$ zinc acetate at room temperature. During batteries measurement, a pure oxygen supply was continuously fed to the cathode. 


\section{Results and discussion}

3.1 Properties of the recycled Ni-Co-Mn oxide materials

$\mathrm{XRF}$ analysis of the cathode materials revealed that $\mathrm{Ni}, \mathrm{Co}$, and $\mathrm{Mn}$ were the main components in the cathode materials, as shown in Table. 1. A small amount of Fe and $\mathrm{Ca}$ is present from the residue of electrolytes. The weight ratio of the metallic elements in the cathode materials from SLIBs was Ni : Co : Mn ; 0.862: 0.137: 0.001. Compared to other reports, the metal content was different to the metal content in bifunctional oxygen electrodes ${ }^{29,30}$. From the XRD data, shown in Figure 2(a), it is clear that the cathode materials from this kind of SLIBs are mainly $\mathrm{LiNi}_{1-\mathrm{x}-\mathrm{y}} \mathrm{Co}_{\mathrm{x}} \mathrm{Mn}_{\mathrm{y}} \mathrm{O}_{2}$ (PDF file: 01075-9200), with the $\alpha-\mathrm{NaFeO}_{2}$-type structure ${ }^{9,31}$. Such materials have shown very good electrochemical behavior, low synthetic cost, high gravimetric and volumetric energy densities, commonly seen with commercial types of lithium nickel-manganese-cobalt oxide materials ${ }^{9,10,32}$.

Table. 1 The metal ingredient content of the cathode materials.

\begin{tabular}{cc}
\hline Metal elements & Contents / wt \% \\
\hline $\mathrm{Co}$ & 9.20 \\
$\mathrm{Ni}$ & 57.85 \\
$\mathrm{Mn}$ & 0.12 \\
$\mathrm{Fe}$ & $<0.01$ \\
$\mathrm{Ca}$ & $<0.01$ \\
\hline
\end{tabular}

Figure.2 (a) XRD patterns (b) SEM image of recycled Ni-Co-Mn oxide powders from cathode of spent lithium ion batteries.

\subsection{Influence of heat-treatment}

Figure 3 TGA/DSC curves for the cathode materials from spent Lithium ion batteries

The cathode materials from SLIBs were heat-treated from room temperature to $900^{\circ} \mathrm{C}$ using the TGA/DSC analyzer at a heating rate of $10{ }^{\circ} \mathrm{C} \min ^{-1}$ in air. Three regions of heat flow were observed (room temperature to $280{ }^{\circ} \mathrm{C}, 280{ }^{\circ} \mathrm{C}$ to $575^{\circ} \mathrm{C}$, and $575{ }^{\circ} \mathrm{C}$ to $900{ }^{\circ} \mathrm{C}$ ), as shown in Figure.3. From room temperature to $280{ }^{\circ} \mathrm{C}$, a weight loss of 4.92 
wt $\%$ was observed, with a DSC peak at $53{ }^{\circ} \mathrm{C}$, which was due to the loss of bound water and organic materials in the cathode materials ${ }^{33}$. From $280{ }^{\circ} \mathrm{C}$ to $575^{\circ} \mathrm{C}$, weight loss of $1.92 \mathrm{wt} \%$ was observed, which resulted from the burning of the acetylene black and the decomposition of the binder (PVDF). From $280{ }^{\circ} \mathrm{C}$ to $575{ }^{\circ} \mathrm{C}$, a significant DSC peak at $550{ }^{\circ} \mathrm{C}$ was observed, indicating a significant phase change of Ni-Co-Mn oxides had occurred at high temperature. A weight loss of $1.51 \mathrm{wt} \%$ was observed from $600{ }^{\circ} \mathrm{C}$ to $900{ }^{\circ} \mathrm{C}$, as a result of he loss of lithium at high temperature and the compaction of powders ${ }^{33}$.

XRD patterns of Ni-Co-Mn oxides prepared with various heat treatments are shown in Figure. 4. From the XRD data, it was clear that the pristine samples and Ni-Co-Mn oxides heated at $300{ }^{\circ} \mathrm{C}$ for 150 min were mainly $\mathrm{LiNi}_{1-\mathrm{x}-\mathrm{y}} \mathrm{Co}_{\mathrm{x}} \mathrm{Mn}_{\mathrm{y}} \mathrm{O}_{2}$ (PDF file: 01-0759200). As shown in Figure. 3(b), there was a small peak of spinel $\mathrm{Co}_{3} \mathrm{O}_{4}$ at $32.45^{\circ}$ and at $33.48^{\circ}{ }^{19}$. Data indicate that Ni-Co-Mn oxides heated at $600{ }^{\circ} \mathrm{C}$ for 60 to $300 \mathrm{~min}$ (PDF file: 00-048-0261) experienced a significant phase change from an $\alpha-\mathrm{NaFeO}_{2}-$ type structure to spinel structure, which offers excellent safety and high power capability owing to the $3 \mathrm{D}$ lattice ${ }^{9,34}$. However, this peak of spinel $\mathrm{Co}_{3} \mathrm{O}_{4}$ disappeared when $\mathrm{Ni}-\mathrm{Co}-\mathrm{Mn}$ oxides was heated at $600{ }^{\circ} \mathrm{C}$ for longer time, due to bivalent atom oxidation. The peaks of Ni-Co-Mn oxides heated at $600{ }^{\circ} \mathrm{C}$ for the longer time were broader and less sharp than those heated at $600^{\circ} \mathrm{C}$ for shorter times, which to some extent may indicate that a longer calcination time was more effective for nanocrystallization of the Ni-Co-Mn oxides ${ }^{30}$. It can be seen that Ni-Co-Mn oxides heated at $900^{\circ} \mathrm{C}$ for $150 \mathrm{~min}$ was mainly $\mathrm{LiNiO}_{2}$ (PDF file: 04-002-0896) with a small amount of $\mathrm{LiCoO}_{2}$ (PDF file: 04-006-4903), which to some extent may explain why some peaks of ternary oxides disappeared. Amongst all samples, carbon residues were present as the minor phases. When the temperature reached $900{ }^{\circ} \mathrm{C}$, the absence of carbon in the XRD pattern indicated that it had burned off ${ }^{33}$.

Figure 4 XRD patterns of Ni-Co-Mn oxides prepared with various heated - treatments. (a) pristine samples and NiCo-Mn oxides heated at $300{ }^{\circ} \mathrm{C}, 600^{\circ} \mathrm{C}$, and $900^{\circ} \mathrm{C}$ for $150 \mathrm{~min}$; (b) Ni-Co-Mn oxides heated at $600^{\circ} \mathrm{C}$ for various times.

The morphology of Ni-Co-Mn oxides prepared with various heated treatments are shown in Figure. 5. It can be seen that there were many caked acetylene black powders, caused by the 
residue of binders (PVDF) in pristine samples. There was less residue of caked acetylene black powders in Ni-Co-Mn oxides heated at higher temperature. It can be seen in Figure. 5(c) (e-f) that there little acetylene black powder remained in Ni-Co-Mn oxides heated at $600^{\circ} \mathrm{C}$. The $\mathrm{Ni}$ Co-Mn oxides powders were caked at $900^{\circ} \mathrm{C}$, as shown in Figure. 5(d).

Figure.5 SEM images of Ni-Co-Mn-C compound prepared with various heated - treatments, (a) pristine, (b) heated at $300^{\circ} \mathrm{C}$ for $150 \mathrm{~min}$, (c) heated at $600^{\circ} \mathrm{C}$ for $150 \mathrm{~min}$, (d) heated at $900^{\circ} \mathrm{C}$ for $150 \mathrm{~min}$, (e) heated at $600^{\circ} \mathrm{C}$ for $300 \mathrm{~min}$, and (f) heated at $600^{\circ} \mathrm{C}$ for $420 \mathrm{~min}$.

\subsection{ORR activity}

The ORR activity of Ni-Co-Mn oxides prepared by various heat-treatments using a catalystcoated rotating disk electrode in terms of the LSVs, is shown in Figure. 6. Figure. 6(a) shows the ORR activities of Ni-Co-Mn oxides heated at various temperatures for 150 min tested at the same conditions. It can be seen that Ni-Co-Mn oxides heated at $600^{\circ} \mathrm{C}$ exhibited a higher ORR performance than others $\left(600^{\circ} \mathrm{C}>300^{\circ} \mathrm{C}>900^{\circ} \mathrm{C}>\right.$ pristine $)$, where the Ni-Co-Mn oxides heated at $600^{\circ} \mathrm{C}$ gave a more positive half-wave potential of $-356 \mathrm{mV}$ and a bigger limiting current density of $1.2 \mathrm{~mA} \mathrm{~cm}^{-2}$. Figure. 6(b) shows the ORR activities of Ni-Co-Mn oxides heated at $600^{\circ} \mathrm{C}$ for various time tested at the same conditions. Amongst the four samples, Ni-Co-Mn oxides heated at $600^{\circ} \mathrm{C}$ for $300 \mathrm{~min}$ exhibited the higher ORR performance. The Ni-Co-Mn oxides heated at $600^{\circ} \mathrm{C}$ for 300 min exhibited a bigger limiting current density of $1.23 \mathrm{~mA} \mathrm{~cm}^{-}$

${ }^{2}$ than that of Ni-Co-Mn oxides heated at other temperatures,. Amongst all samples, the limiting current density was smaller than that of Pt/C catalysts (approximately $2.2 \mathrm{~mA}$ ) ${ }^{30}$, which was mainly owing to low conductivity of the powders, shown in Table.2 and Table.3. Ovewrall, the results indicate that temperature and time have significant influences on the ORR activity of $\mathrm{Ni}-\mathrm{Co}-\mathrm{Mn}$ oxides produced from spent lithium ion batteries cathode materials.

a

There are two pathways for ORR mechanism: the four electron pathway and the two electron pathway ${ }^{35}$. The preferred electron transfer number (n) is one of the important factors in evaluation of ORR catalysts, which ideally should be four ${ }^{28}$. The ORR pathways is mainly affected by crystallographic structure created by heated-treatment ${ }^{22}$. As shown in Figure.7, the electron transfer number on Ni-Co-Mn oxides heated at $600^{\circ} \mathrm{C}$ for $300 \mathrm{~min}$ was approximately 3.6, which was much more than the value of 2.7 for pristine samples produced directly from SLIBs. The pathways for ORR mechanism of Ni-Co-Mn oxides heated at $600^{\circ} \mathrm{C}$ for $300 \mathrm{~min}$ was mainly the direct four electron pathway whilst the pathways for ORR mechanism of pristine samples was mainly the successive two electron pathway. This difference is due to the $\mathrm{Ni}-\mathrm{Co}-\mathrm{Mn}$ oxides heated at $600^{\circ} \mathrm{C}$ for $300 \mathrm{~min}$ experiencing a significant phase change from $\alpha$ - 
$\mathrm{NFeO}_{2}$-type structure to a spinel structure. The four electron pathway is desirable due to its high energy efficiency ${ }^{22}$.

Figure.6 (a)LCV curves of ORR measured at $10 \mathrm{mV} \mathrm{s}^{-1}$ in $1 \mathrm{~mol} \mathrm{~L}^{-1} \mathrm{KOH}$ for Ni-Co-Mn oxides heated at various temperatures for $150 \mathrm{~min}$, (b) heated at $600{ }^{\circ} \mathrm{C}$ for various time.

Figure. 7 (a)The i-E curves of ring and disk electrodes on RRDE and (b) the electron transfer number of pristine samples and $\mathrm{Ni}-\mathrm{Co}-\mathrm{C}$ compounds heated at $600^{\circ} \mathrm{C}$ for $300 \mathrm{~min}$.

\subsection{OER activity}

The nickel and cobalt are considered as key catalytically active metal species for the OER ${ }^{36}$. Figure. 8 shows anodic linear sweep voltammograms for the OER on the Ni-Co-Mn oxides prepared with various heat-treatments. In the potential range $300-375 \mathrm{mV}$, these Ni-Co-Mn oxides exhibited anodic peaks typical of spinel cobaltite electrodes, which were followed by the onset points of oxygen evolution ${ }^{30}$. Amongst all samples heated at $600^{\circ} \mathrm{C}$, the anodic peaks of Ni-Co-Mn oxides were at potentials much positive that other catalysts ${ }^{23,37}$. As shown in Figure. $8(\mathrm{a})$, Ni-Co-Mn oxides heated at $600^{\circ} \mathrm{C}$ for $150 \mathrm{~min}$ exhibits a much better OER performance than other samples heated at various temperatures for 150min; with the Ni-Co-Mn oxides heated at $600^{\circ} \mathrm{C}$ for $150 \mathrm{~min}$ giving an onset potential of $235 \mathrm{mV}$ and a half-wave potential of $290 \mathrm{mV}$ more negative than that of other samples, at $30^{\circ} \mathrm{C}$, respectively. It can be seen from Figure. 8 (b) that Ni-Co-Mn oxides heated at $600^{\circ} \mathrm{C}$ for $300 \mathrm{~min}$ showed better OER performances than that for other Ni-Co-Mn oxides heated at $600^{\circ} \mathrm{C}$ for different times, where the $\mathrm{Ni}-\mathrm{Co}-\mathrm{Mn}$ oxides heated at $600^{\circ} \mathrm{C}$ for $300 \mathrm{~min}$ can give an onset potential of $235 \mathrm{mV}$ and a half-wave potential of $250 \mathrm{mV}$ more negative than that of other samples at $30^{\circ} \mathrm{C}$.

The apparent activation energy (Ea) at a constant pressure $p$, a certain overpotential $\eta$ and certain concentrations of reactants $C_{i}$ were determined from plots of $\log (i)$ vs. $T^{-1}$ (at, $30^{\circ} \mathrm{C}$, $40^{\circ} \mathrm{C}, 50^{\circ} \mathrm{C}$, and $60^{\circ} \mathrm{C}$ ) using the Arrhenius relationship ${ }^{38}$ :

$$
E_{a}=-R\left[\frac{\partial \ln i}{\partial\left(\frac{1}{T}\right)}\right]_{p ; \eta ; C i}
$$

Where, $\mathrm{R}=8.314$.

It can be seen from Table. 2 and Table. 3 that the apparent activation energies at $\eta=250 \mathrm{mV}$ of $\mathrm{Ni}-\mathrm{Co}-\mathrm{Mn}$ oxides heated at $600^{\circ} \mathrm{C}$ for $300 \mathrm{~min}$ were approximately $4.34 \mathrm{~kJ} \mathrm{~mol}^{-1}$ and was much lower than that for Ni-Co-Mn oxides prepared with other heated-treatments. The apparent activation energies Ni-Co-Mn oxides was much lower that reported for other catalysts ${ }^{38}$. 
Table. 2 Properties of Ni-Co-Mn oxides heated at various temperatures for 150min.

\begin{tabular}{|c|c|c|c|c|}
\hline Treatment Temperature $/{ }^{\circ} \mathrm{C}$ & pristine & 300 & 600 & 900 \\
\hline $\begin{array}{l}\text { Electrical conductivity / } \\
\qquad \mathrm{mS} \mathrm{mm}^{-1}\end{array}$ & 0.0105 & 0.0119 & 0.1900 & 0.0066 \\
\hline $\begin{array}{l}\text { Apparent activation energies } \\
\text { at } \eta=250 \mathrm{mV} / \mathrm{kJ} \mathrm{mol}^{-1}\end{array}$ & 49.20 & 38.73 & 8.47 & 42.16 \\
\hline
\end{tabular}

Table. 3 Properties of Ni-Co-Mn oxides heated at $600{ }^{\circ} \mathrm{C}$ for various time.

\begin{tabular}{|c|c|c|c|c|c|c|}
\hline Time / min & 60 & 120 & 240 & 300 & 360 & 420 \\
\hline \multicolumn{7}{|l|}{ Electric conductivity } \\
\hline I & 0.0001 & 0.0003 & 0.1200 & 0.2200 & 0.2200 & 0.2300 \\
\hline \multicolumn{7}{|l|}{$\mathbf{m S ~ m m ^ { - 1 }}$} \\
\hline \multicolumn{7}{|l|}{ Apparent activation } \\
\hline energies at $\eta=250$ & - & - & 4.86 & 4.34 & 5.37 & 5.58 \\
\hline $\mathrm{mV} / \mathrm{kJ} \mathrm{mol}^{-1}$ & & & & & & \\
\hline
\end{tabular}

Figure.8 (a) LCV curves of OER measured at $0.5 \mathrm{mV} \mathrm{s}^{-1}$ in $1 \mathrm{~mol} \mathrm{~L}^{-1} \mathrm{KOH}$ for Ni-Co-Mn oxides heated at various temperatures for $150 \mathrm{~min}$, (b) heated at $600{ }^{\circ} \mathrm{C}$ for various time.

\subsection{Performances in zinc-air batteries}

Figure.9 (a)Discharge and charge polarization curves and the power density against the discharge current density plot of zinc-air battery using Ni-Co-Mn oxides heated at various temperatures for $150 \mathrm{~min}$, (b) heated at $600^{\circ} \mathrm{C}$ for various time.

Figure.10 Charge-discharge-cycling curves of zinc-battery using Ni-Co-Mn oxides renovated through various heattreatment at $10 \mathrm{~mA} \mathrm{~cm}^{-2}$.

Figure. 9 shows discharge and charge polarization curves of the zinc-air battery with the air electrode prepared with Ni-Co-Mn oxides created through various heat-treatment and zinc foil in $6 \mathrm{M} \mathrm{KOH}+0.2 \mathrm{M}$ zinc acetate. It can be seen from Figure. 9(a) that the zinc-air battery using $\mathrm{Ni}-\mathrm{Co}-\mathrm{Mn}$ oxides heated at $600^{\circ} \mathrm{C}$ for $150 \mathrm{~min}$ performed better in both discharge curves and charge curves than that using Ni-Co-Mn oxides heated at various temperatures for $150 \mathrm{~min}$. As shown in Figure9(b), the zinc-air battery using Ni-Co-Mn oxides heated at $600^{\circ} \mathrm{C}$ for $300 \mathrm{~min}$ 
performed best in both discharge curves and charge curves. The open circuit voltage of this zinc-air battery was approximately $1.3 \mathrm{~V}$, which lower than the nominal open-circuit voltage for a zinc-air battery $(1.4 \mathrm{~V}) 100 \mathrm{mV}^{10}$. It can be seen that there is nearly linear decrease of cell voltage with current density in the discharge curve at current densities higher than $10 \mathrm{~mA} \mathrm{~cm}^{-2}$, indicating a transition from the activation polarization situation to the Ohmic and diffusion polarization state ${ }^{27}$. Figure.10 displays ten charge-discharge cycles of the zinc-air battery with air electrode prepared with $\mathrm{Ni}-\mathrm{Co}-\mathrm{Mn}$ oxides created through various heat-treatment onto carbon paper measured at $10 \mathrm{~mA} \mathrm{~cm}{ }^{-2}$ in $6 \mathrm{M} \mathrm{KOH}+0.2 \mathrm{M}$ zinc acetate under a pure oxygen supply. Such batteries exhibited cycling stability when charged and discharged at low current density $\left(10 \mathrm{~mA} \mathrm{~cm}^{-2}\right)$ in short cycles time (120s). The zinc-air battery using Ni-Co-Mn oxides heated at $600^{\circ} \mathrm{C}$ for $300 \mathrm{~min}$ performed best of materials tested. The charge voltage (approximately $1.5 \mathrm{~V}$ ) and discharge voltage (approximately $1.1 \mathrm{~V}$ ) of this zinc-air battery exhibited excellent cycling stability. The calculated energy efficiency of this zinc-air battery (approximately 75\%) was better than commercial zinc-air batteries, which discharges at a voltage of around $1.1 \mathrm{~V}$, while the charging voltage is around $1.6 \mathrm{~V}$ or higher ${ }^{10}$. There were no ionomers in the three phase boundary in the air electrode of this study, which may result in limited ORR activities ${ }^{30}$. The charge voltage was about $0.1 \mathrm{~V}$ lower than some commercial zinc-air batteries ${ }^{10}$, which agrees with the results on the OER activities of the Ni-Co-Mn oxides. 


\section{Conclusions}

For the first time a method to directly reuse Ni-Co-Mn oxides from spent lithium ion batteries (SLIBs) to prepare air electrodes is reported. Heat-treatment at $600^{\circ} \mathrm{C}$ could change the $\mathrm{Ni}-\mathrm{Co}-$ $\mathrm{Mn}$ oxides from an $\alpha-\mathrm{NaFeO}_{2}$-type structure to a spinel structure. The recycled $\mathrm{Ni}-\mathrm{Co}-\mathrm{Mn}$ oxides heated at $600^{\circ} \mathrm{C}$ for $300 \mathrm{~min}$ exhibited the best electrochemical activity than samples with different heat-treatment parameters. The Ni-Co-Mn oxides showed a direct four electron pathway for ORR. The calculated energy efficiency of this zinc-air battery was approximately $75 \%$, and better than commercial zinc-air batteries, indicating their promising applications. Compared with traditional SLIBs recycling procedures, the recycling process in this study is simple with prospective environmental and economic benefits. This study might also initiate topics on inexpensive air electrodes prepared with recycled materials from spent batteries. However in this study, we achieved relatively low current densities, due to lack of ionomers in the electrode three phase boundary. Key performance indicaters (KPI) of air electrodes such as stability and power density performance will be investigated with $\mathrm{Ni-Co}$ oxides recycled from SLIBs in future works. Meanwhile, the influences of Ni:Co:Mn ratios will be studied regarding their electrochemical properties. In this study, only Ni-Co-Mn oxide material form SLIBs, as an example, was investigated for direct reuse in new electrochemical devices. It is also important to investigate all types of metal oxides from SLIBs, for example directly reusing $\mathrm{LiCoO}_{2}, \mathrm{LiMn}_{2} \mathrm{O}_{4}$, and $\mathrm{LiFePO}_{4}$ materials from SLIBs to prepare various suitable electrochemical devices, such as air batteries, fuel cells, and electrolysers.

\section{Acknowledgement}

The authors would like to acknowledge the Thousands Youth Talents Project of China, which sponsors Prof $\mathrm{Xu}$ Wu to establish a research group at Huazhong University of Science and Technology. 


\section{References}

[1] http://www.cbea.com/html/www/ldc/201608/ff808081566cf33701567729cf5c030b.html.

[2] Chagnes, A.; Pospiech, B., A brief review on hydrometallurgical technologies for recycling spent lithium-ion batteries. Journal of Chemical Technology and Biotechnology 2013, 88, (7), 1191-1199.

[3] Zeng, X.; Li, J.; Singh, N., Recycling of Spent Lithium-Ion Battery: A Critical Review. Critical Reviews in Environmental Science and Technology 2014, 44, (10), 1129-1165.

[4] Huang, B.; Yang, J.; Wang, J.; Analysis and suggestion on the resource utilization method of waste lithium-ion battery. Renewable Resources and Circular Economy 2015, 28-33.

[5] Georgi-Maschler, T.; Friedrich, B.; Weyhe, R.; Heegn, H.; Rutz, M., Development of a recycling process for Li-ion batteries. Journal of Power Sources 2012, 207, 173-182.

[6] Li, L.; Ge, J.; Chen, R.; Wu, F.; Chen, S.; Zhang, X., Environmental friendly leaching reagent for cobalt and lithium recovery from spent lithium-ion batteries. Waste Manag 2010, 30, (12), 2615-21.

[7] Zou, H.; Gratz, E.; Apelian, D.; Wang, Y., A novel method to recycle mixed cathode materials for lithium ion batteries. Green Chemistry 2013, 15, (5), 1183-1191.

[8] Edström, K.; Gustafsson, T.; Thomas, J. O., The cathode-electrolyte interface in the Li-ion battery. Electrochimica Acta 2004, 50, (2-3 SPEC. ISS.), 397-403.

[9] Ellis, B. L.; Lee, K. T.; Nazar, L. F., Positive electrode materials for Li-Ion and Li-batteries. Chemistry of Materials 2010, 22, (3), 691-714.

[10] Thomas Reddy-Linden's Handbook of Batteries, 4th Edition-McGraw-Hill Professional (2010).

[11] Etacheri, V.; Marom, R.; Elazari, R.; Salitra, G.; Aurbach, D., Challenges in the development of advanced Li-ion batteries: A review. Energy and Environmental Science 2011, 4, (9), 3243-3262.

[12] Goodenough, J. B.; Park, K. S., The Li-Ion Rechargeable Battery: A Perspective. Journal of the American Chemical Society 2013, 135, (4), 1167-1176.

[13] Kang, K.; Meng, Y. S.; Bréger, J.; Grey, C. P.; Ceder, G., Electrodes with high power and high capacity for rechargeable lithium batteries. Science 2006, 311, (5763), 977-980.

[14] Contestabile, M.; Panero, S.; Scrosati, B., A laboratory-scale lithium-ion battery recycling process. Journal of Power Sources 2001, 92, (1-2), 65-69.

[15] Ra, D. i.; Han, K. S., Used lithium ion rechargeable battery recycling using Etoile-Rebatt technology. Journal of Power Sources 2006, 163, (1 SPEC. ISS.), 284-288.

[16] Garcia, E. M.; Tarôco, H. A.; Matencio, T.; Domingues, R. Z.; dos Santos, J. A. F.; Ferreira, R. V.; Lorençon, E.; Lima, D. Q.; de Freitas, M. B. J. G., Electrochemical recycling of cobalt from spent cathodes of lithium-ion batteries: its application as supercapacitor. Journal of Applied Electrochemistry 2012, 42, (6), 361-366.

[17] Garcia, E. M.; Tarôco, H. A.; Matencio, T.; Domingues, R. Z.; dos Santos, J. A. F.; de Freitas, M. B. J. G., Electrochemical recycling of cobalt from spent cathodes of lithium-ion batteries: its application as coating on SOFC interconnects. Journal of Applied Electrochemistry 2011, 41, (11), 1373-1379.

[18] Liu, Y.; Hu, Q.; Li, X.; Wang Z.; Guo, H.; Peng, W.; Study on the direct recovery $\mathrm{LiCoO}_{2}$ from the Li-ion battery. Chinese Journal of Power Sources 2006, 308-310.

[19] Liu, Y.; Hu, Q.; Li, X.; Wang, Z.; Guo, H.; Peng, W.; Recovery of LiCoO2 and its electrochemical performance. The Chinese Journal of Nonferrous Metals, 2007, 984-989.

[20] Ma, Z.; Yuan, X.; Li, L.; Ma, Z. F.; Wilkinson, D. P.; Zhang, L.; Zhang, J., A review of cathode materials and structures for rechargeable lithium-air batteries. Energy and Environmental Science 2015, 
8, (8), 2144-2198.

[21] Neburchilov, V.; Wang, H.; Martin, J. J.; Qu, W., A review on air cathodes for zinc-air fuel cells. Journal of Power Sources 2010, 195, (5), 1271-1291.

[22] Cheng, F.; Chen, J., Metal-air batteries: From oxygen reduction electrochemistry to cathode catalysts. Chemical Society Reviews 2012, 41, (6), 2172-2192.

[23] Wu, X.; Scott, K., A Li-doped Co3O4 oxygen evolution catalyst for non-precious metal alkaline anion exchange membrane water electrolysers. International Journal of Hydrogen Energy 2013, 38, (8), 3123-3129.

[24] Liu, J.; Liu, H.; Wang, F.; Song, Y., Composition-controlled synthesis of LixCo3-xO4 solid solution nanocrystals on carbon and their impact on electrocatalytic activity toward oxygen reduction reaction. RSC Advances 2015, 5, (110), 90785-90796.

[25] Wang, B.; Cai, Y.; Dong, W.; Xia, C.; Zhang, W.; Liu, Y.; Afzal, M.; Wang, H.; Zhu, B., Photovoltaic properties of LixCo3-xO4/TiO2 heterojunction solar cells with high open-circuit voltage. Solar Energy Materials and Solar Cells 2016, 157, 126-133.

[26] Oh, S. W.; Myung, S. T.; Kang, H. B.; Sun, Y. K., Effects of Co doping on Li Ni0.5CoxMn1.5-x O4 spinel materials for $5 \mathrm{~V}$ lithium secondary batteries via Co-precipitation. Journal of Power Sources 2009, 189, (1), 752-756.

[27] Li, P. C.; Chien, Y. J.; Hu, C. C., Novel configuration of bifunctional air electrodes for rechargeable zinc-air batteries. Journal of Power Sources 2016, 313, 37-45.

[28] Xia, W.; Zou, R.; An, L.; Xia, D.; Guo, S., A metal-organic framework route to in situ encapsulation of Co@Co3O4@C core@bishell nanoparticles into a highly ordered porous carbon matrix for oxygen reduction. Energy \& Environmental Science 2015, 8, (2), 568-576.

[29] Neburchilov, V.; Wang, H. J.; Martin, J. J.; Qu, W., A review on air cathodes for zinc-air fuel cells. Journal of Power Sources 2010, 195, (5), 1271-1291.

[30] Wu, X.; Scott, K., A non-precious metal bifunctional oxygen electrode for alkaline anion exchange membrane cells. Journal of Power Sources 2012, 206, 14-19.

[31] Fujii, Y.; Miura, H.; Suzuki, N.; Shoji, T.; Nakayama, N., Structural and electrochemical properties of LiNi1/3Co1/3Mn1/3O2-LiMg1/3Co1/3Mn1/3O2 solid solutions. Solid State Ionics 2007, 178, (1112), 849-857.

[32] Yabuuchi, N.; Yoshii, K.; Myung, S. T.; Nakai, I.; Komaba, S., Detailed studies of a high-capacity electrode material for rechargeable batteries, Li2MnO3-LiCo1/3Ni 1/3Mn1/3O2. Journal of the American Chemical Society 2011, 133, (12), 4404-4419.

[33] Li, L.; Lu, J.; Ren, Y.; Zhang, X. X.; Chen, R. J.; Wu, F.; Amine, K., Ascorbic-acid-assisted recovery of cobalt and lithium from spent Li-ion batteries. Journal of Power Sources 2012, 218, 21-27.

[34] Kawai, H.; Nagata, M.; Tukamoto, H.; West, A. R., A novel cathode Li2CoMn3O8 for lithium ion batteries operating over 5 volts. Journal of Materials Chemistry 1998, 8, (4), 837-839.

[35] Jorissen, L., Bifunctional oxygen/air electrodes. Journal of Power Sources 2006, 155, (1), 23-32.

[36] Jiang, J.; Zhang, A.; Li, L.; Ai, L., Nickel-cobalt layered double hydroxide nanosheets as highperformance electrocatalyst for oxygen evolution reaction. Journal of Power Sources 2015, 278, 445451.

[37] Li, Y.; Gong, M.; Liang, Y.; Feng, J.; Kim, J. E.; Wang, H.; Hong, G.; Zhang, B.; Dai, H., Advanced zinc-air batteries based on high-performance hybrid electrocatalysts. Nature Communications 2013, 4.

[38] Wu, X.; Scott, K.; Puthiyapura, V., Polymer electrolyte membrane water electrolyser with Aquivion 
(B) short side chain perfluorosulfonic acid ionomer binder in catalyst layers. International Journal of Hydrogen Energy 2012, 37, (18), 13243-13248. 


\section{Caption List:}

Figure. 1 Illustration of different treatments of spent Lithium ion batteries.

Figure.2 (a) XRD patterns (b) SEM image of recycled Ni-Co-Mn oxide powders from cathode of spent lithium ion batteries.

Figure 3 TGA/DSC curves for the cathode materials from spent Lithium ion batteries

Figure 4 XRD patterns of Ni-Co-Mn oxides prepared with various heated - treatments. (a) pristine samples and Ni-Co-Mn oxides heated at $300{ }^{\circ} \mathrm{C}, 600{ }^{\circ} \mathrm{C}$, and $900{ }^{\circ} \mathrm{C}$ for $150 \mathrm{~min}$; (b) Ni-Co-Mn oxides heated at $600{ }^{\circ} \mathrm{C}$ for various times.

Figure.5 SEM images of Ni-Co-Mn-C compound prepared with various heated - treatments, (a) pristine, (b) heated at $300^{\circ} \mathrm{C}$ for $150 \mathrm{~min}$, (c) heated at $600^{\circ} \mathrm{C}$ for $150 \mathrm{~min}$, (d) heated at $900^{\circ} \mathrm{C}$ for $150 \mathrm{~min}$, (e) heated at $600^{\circ} \mathrm{C}$ for $300 \mathrm{~min}$, , and (f) heated at $600^{\circ} \mathrm{C}$ for $420 \mathrm{~min}$.

Figure.6 (a)LCV curves of ORR measured at $10 \mathrm{mV} \mathrm{s}^{-1}$ in $1 \mathrm{~mol} \mathrm{~L}^{-1} \mathrm{KOH}$ for Ni-Co-Mn oxides heated at various temperatures for $150 \mathrm{~min}$, (b) heated at $600^{\circ} \mathrm{C}$ for various time.

Figure. 7 (a)The i-E curves of ring and disk electrodes on RRDE and (b) the electron transfer number of pristine samples and Ni-Co-C compounds heated at $600^{\circ} \mathrm{C}$ for $300 \mathrm{~min}$. Figure.8 (a) LCV curves of OER measured at $0.5 \mathrm{mV} \mathrm{s}^{-1}$ in $1 \mathrm{~mol} \mathrm{~L}^{-1} \mathrm{KOH}$ for Ni-Co-Mn oxides heated at various temperatures for $150 \mathrm{~min}$, (b) heated at $600{ }^{\circ} \mathrm{C}$ for various time.

Figure.9 (a)Discharge and charge polarization curves and the power density against the discharge current density plot of zinc-air battery using Ni-Co-Mn oxides heated at various temperatures for $150 \mathrm{~min}$, (b) heated at $600^{\circ} \mathrm{C}$ for various time.

Figure.10 Charge-discharge-cycling curves of zinc-battery using Ni-Co-Mn oxides renovated through various heat-treatment at $10 \mathrm{~mA} \mathrm{~cm}^{-2}$.

Table. 1 The metal ingredient content of the cathode materials.

Table. 2 Properties of Ni-Co-Mn oxides heated at various temperatures for 150min.

Table. 3 Properties of Ni-Co-Mn oxides heated at $600{ }^{\circ} \mathrm{C}$ for various time. 

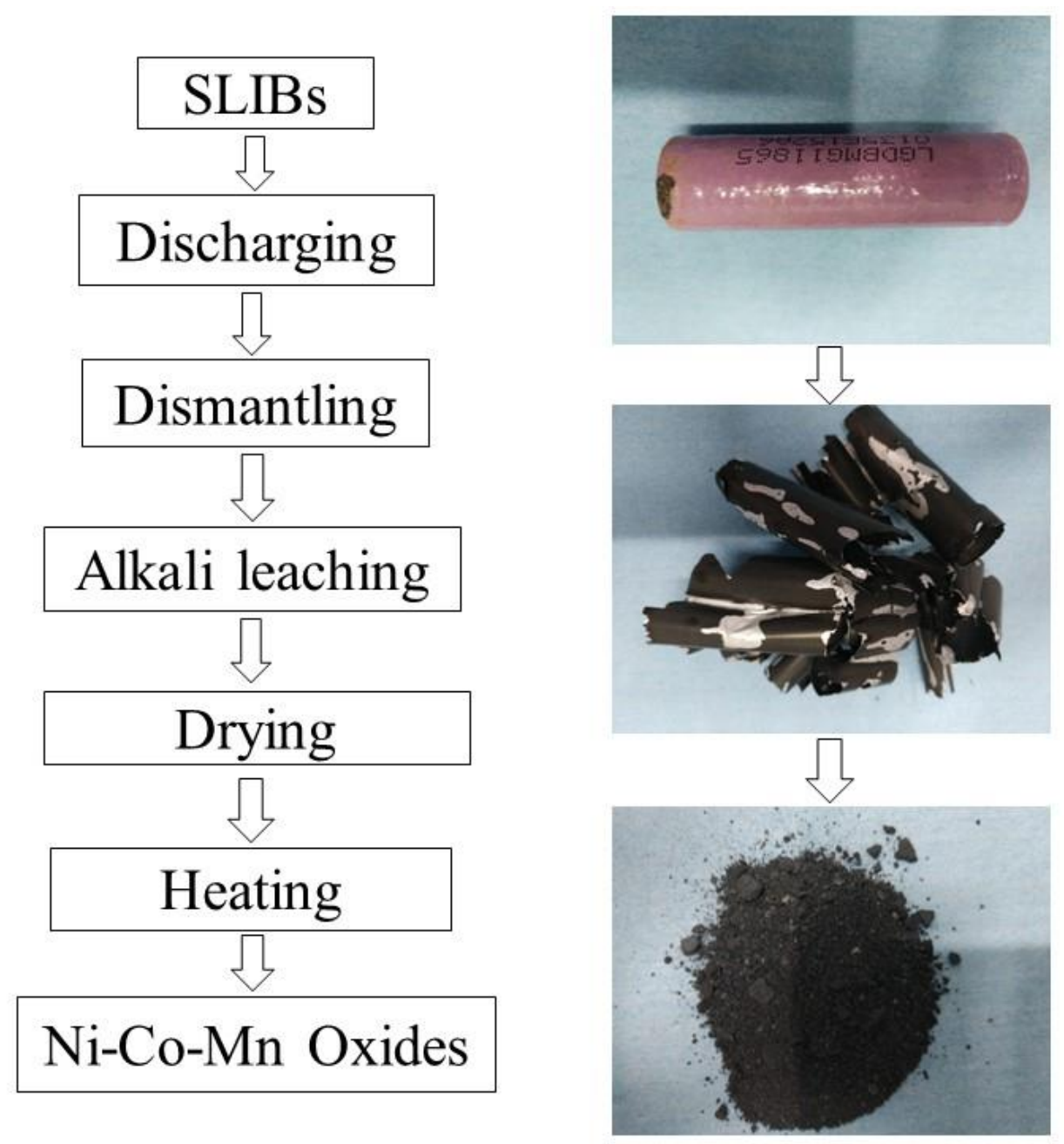

Figure. 1 Illustration of different treatments of spent Lithium ion batteries.
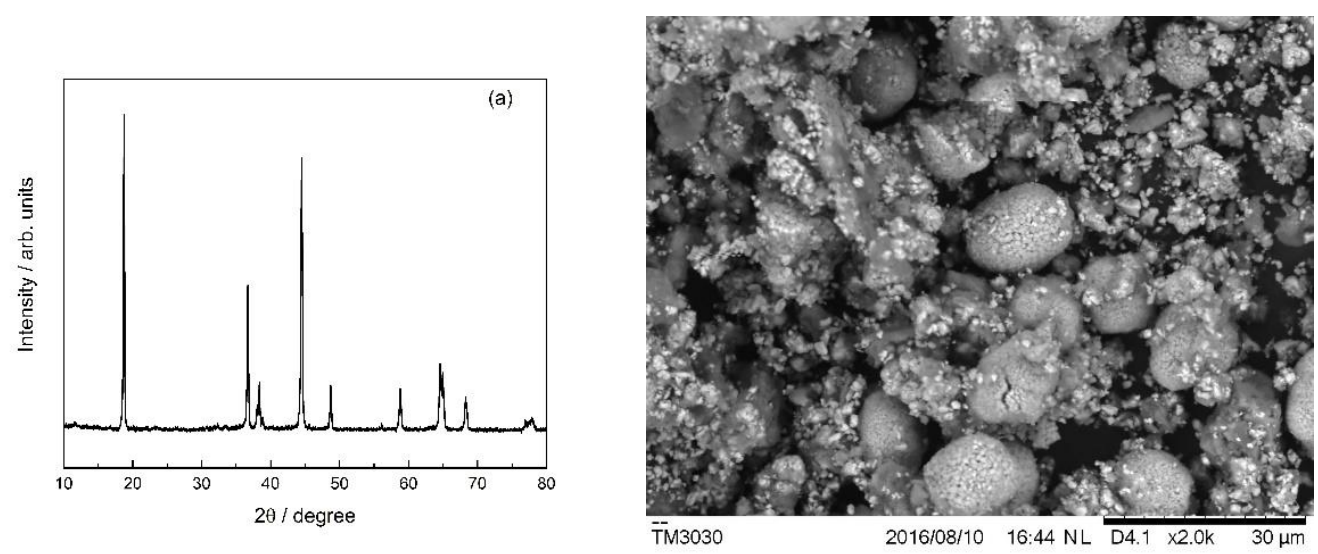

Figure.2 (a) XRD patterns (b) SEM image of recycled Ni-Co-Mn oxide powders from cathode of spent lithium ion batteries. 


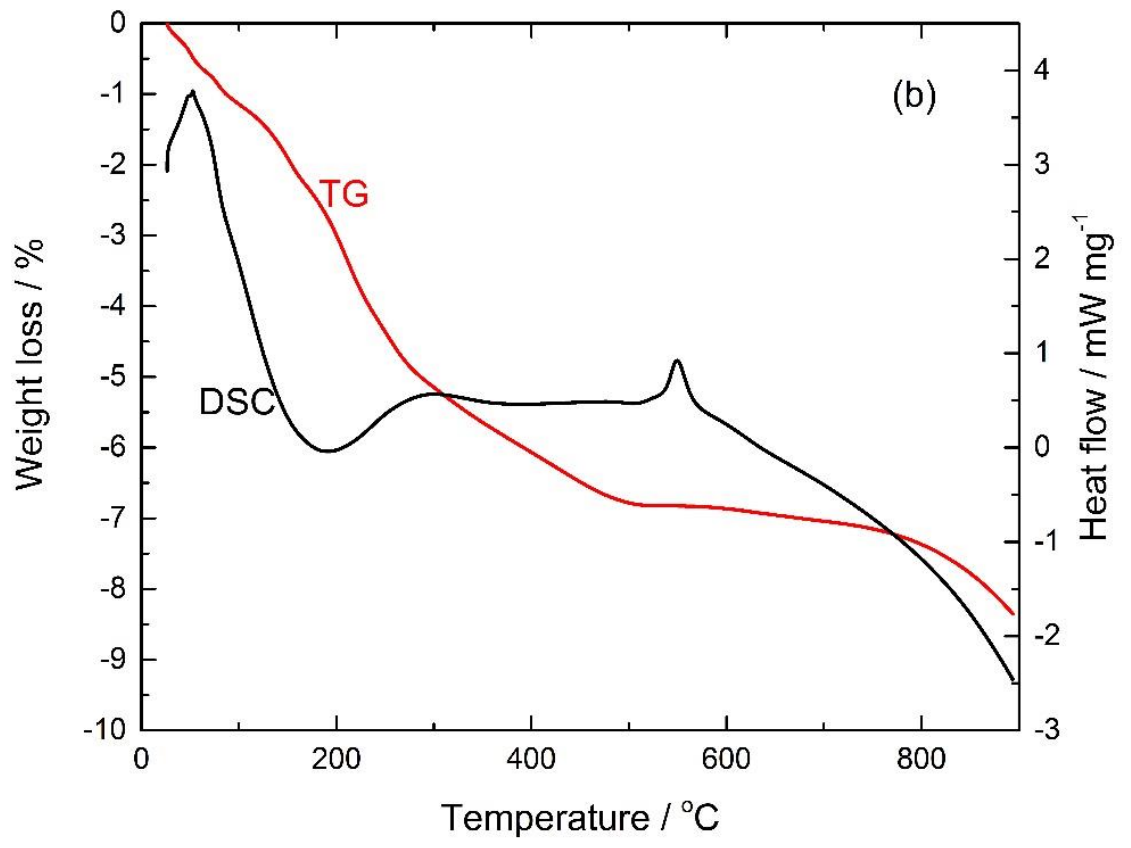

Figure 3 TGA/DSC curves for the cathode materials from spent Lithium ion batteries 

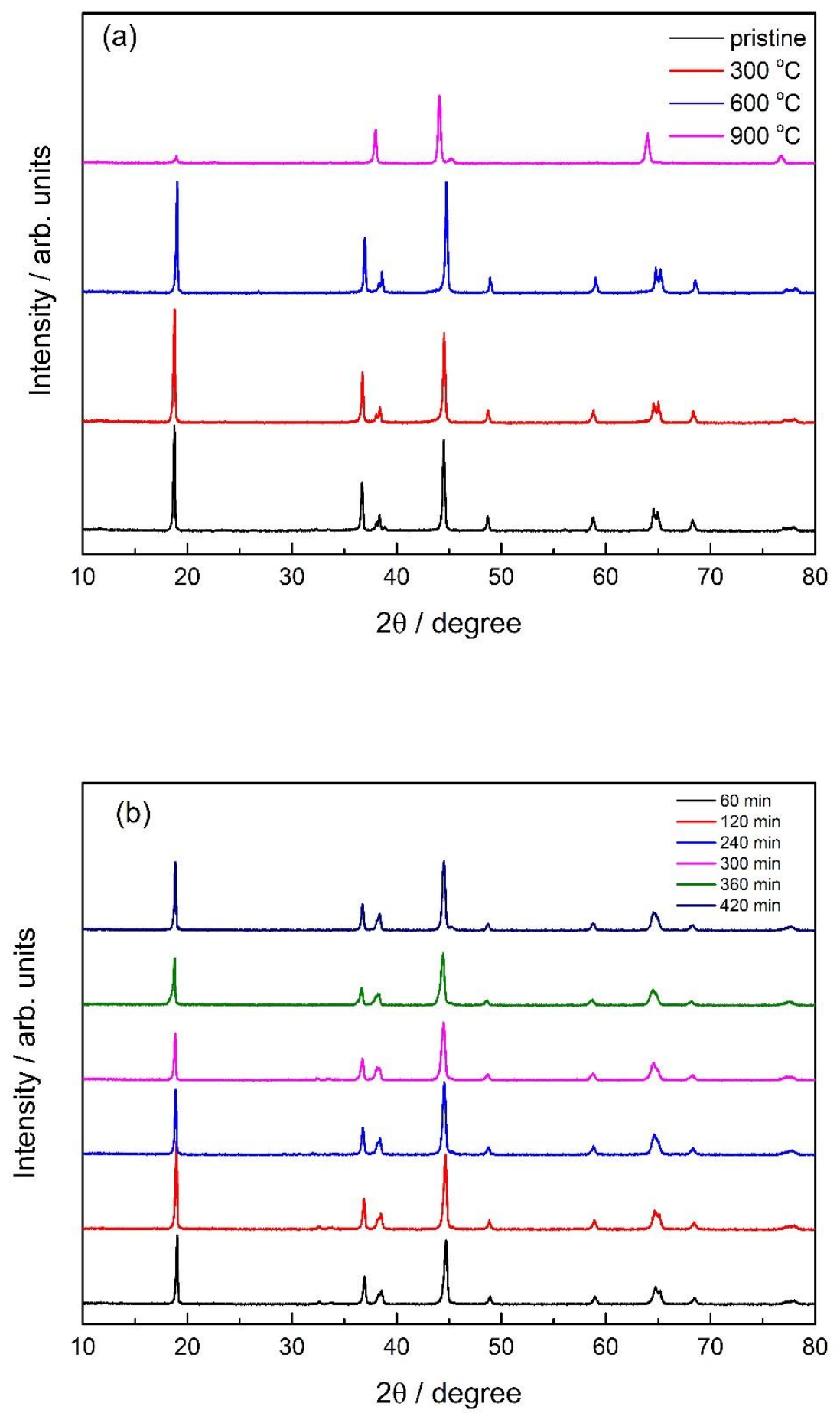

Figure 4 XRD patterns of Ni-Co-Mn oxides prepared with various heated - treatments. (a) pristine samples and Ni-Co-Mn oxides heated at $300{ }^{\circ} \mathrm{C}, 600^{\circ} \mathrm{C}$, and $900{ }^{\circ} \mathrm{C}$ for $150 \mathrm{~min}$; (b) Ni-Co-Mn oxides heated at $600^{\circ} \mathrm{C}$ for various times. 


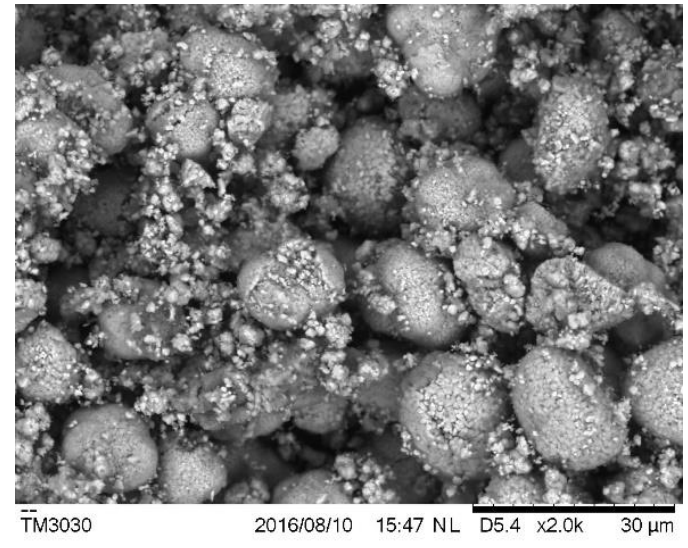

(a)

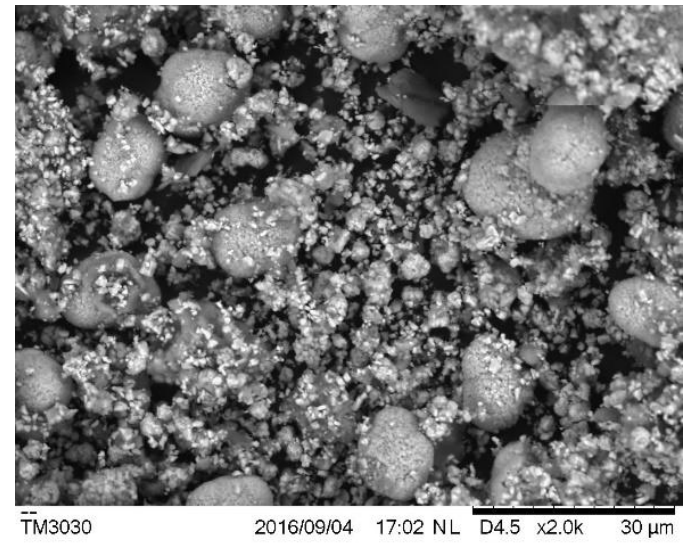

(c)

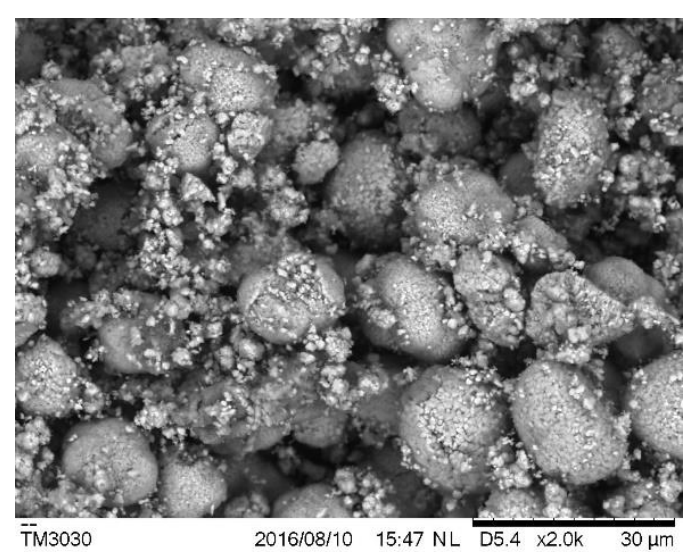

(e)

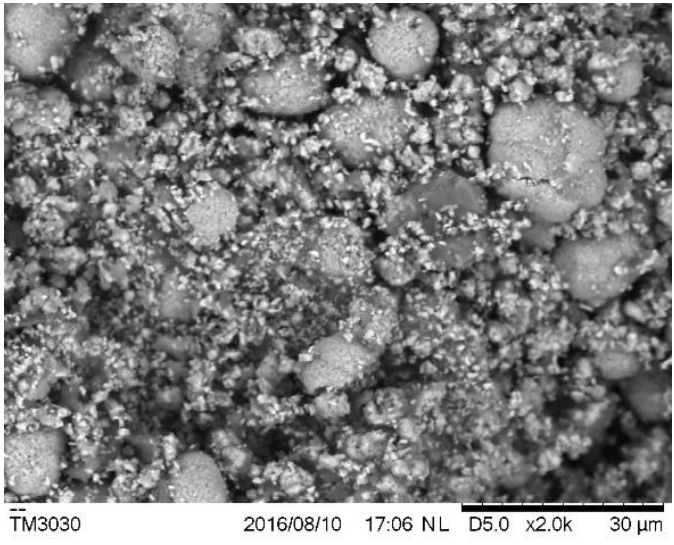

(b)

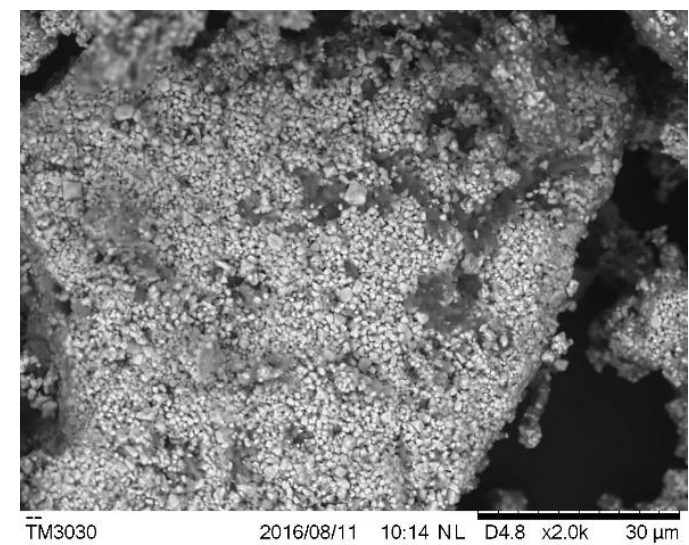

(d)

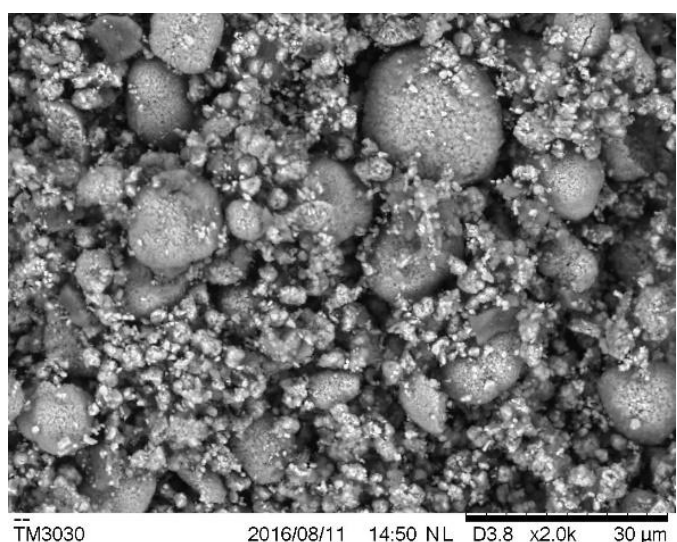

(f)

Figure.5 SEM images of Ni-Co-Mn-C compound prepared with various heated - treatments, (a) pristine, (b) heated at $300^{\circ} \mathrm{C}$ for $150 \mathrm{~min}$, (c) heated at $600^{\circ} \mathrm{C}$ for $150 \mathrm{~min}$, (d) heated at $900^{\circ} \mathrm{C}$ for $150 \mathrm{~min}$, (e) heated at $600^{\circ} \mathrm{C}$ for $300 \mathrm{~min}$, and (f) heated at $600^{\circ} \mathrm{C}$ for $420 \mathrm{~min}$. 

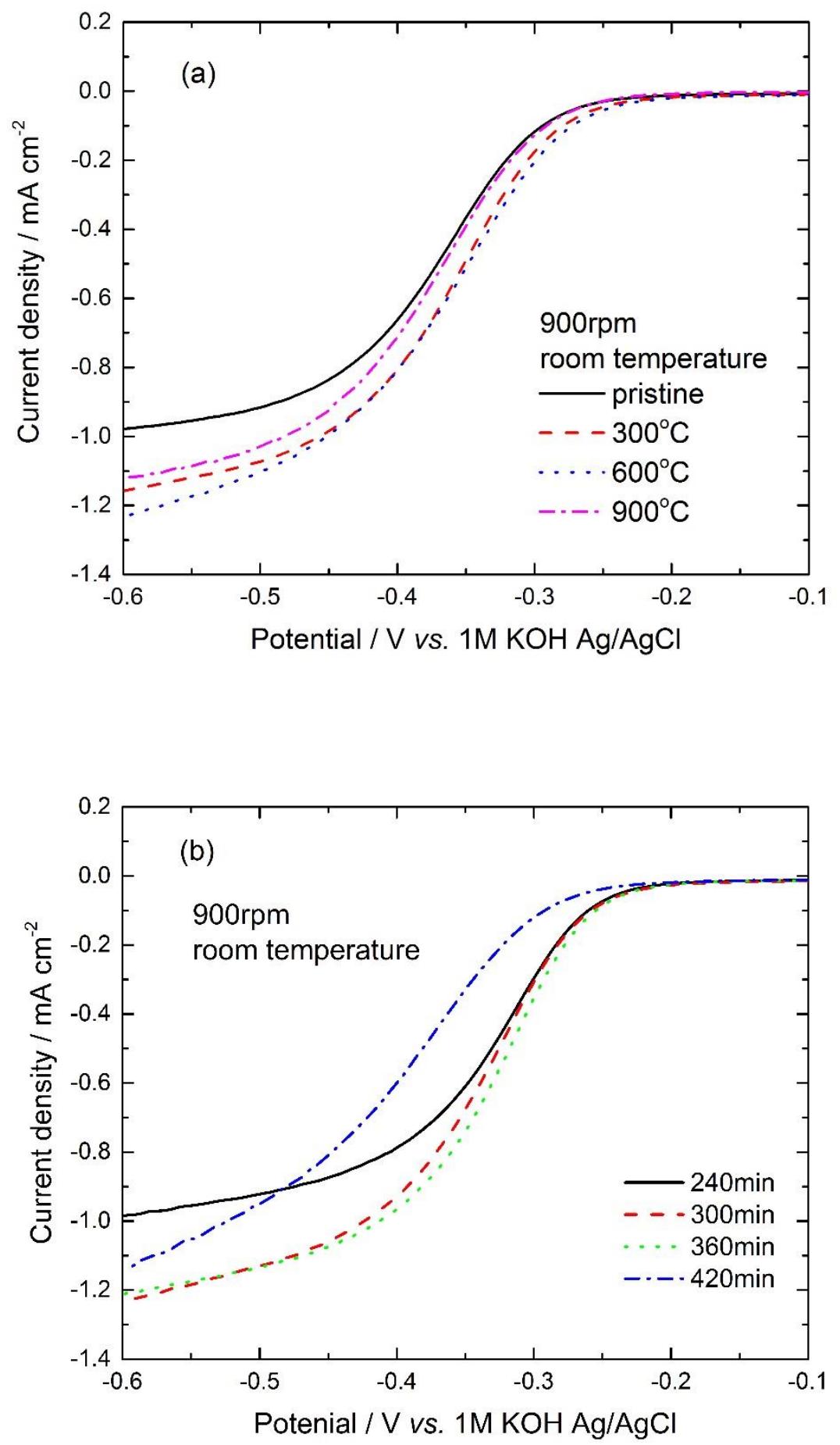

Figure.6 (a)LCV curves of ORR measured at $10 \mathrm{mV} \mathrm{s}^{-1}$ in $1 \mathrm{~mol} \mathrm{~L}^{-1} \mathrm{KOH}$ for Ni-Co-Mn oxides heated at various temperatures for $150 \mathrm{~min}$, (b) heated at $600{ }^{\circ} \mathrm{C}$ for various time. 

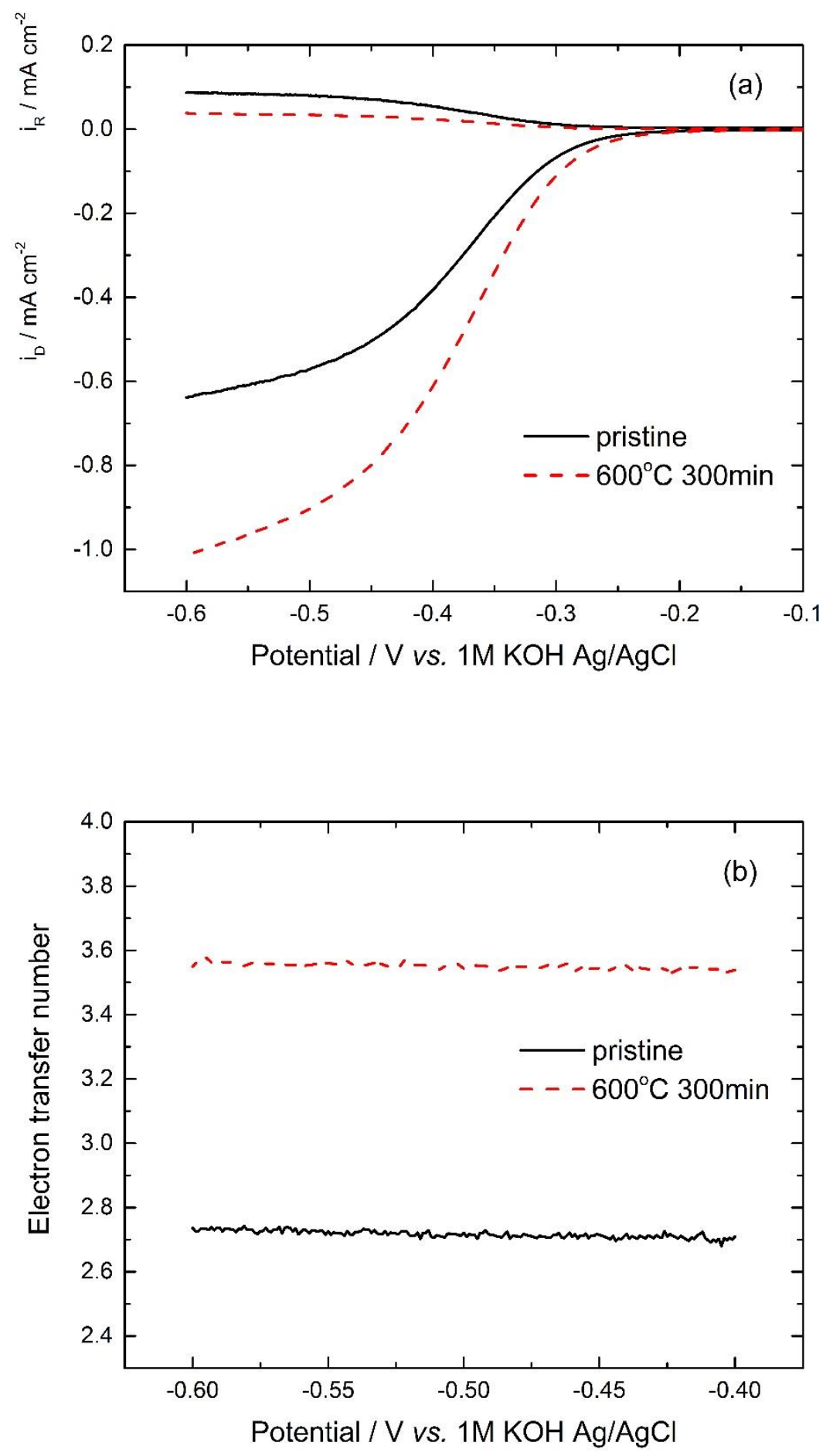

Figure. 7 (a)The i-E curves of ring and disk electrodes on RRDE and (b) the electron transfer number of pristine samples and $\mathrm{Ni}-\mathrm{Co}-\mathrm{C}$ compounds heated at $600^{\circ} \mathrm{C}$ for $300 \mathrm{~min}$. 

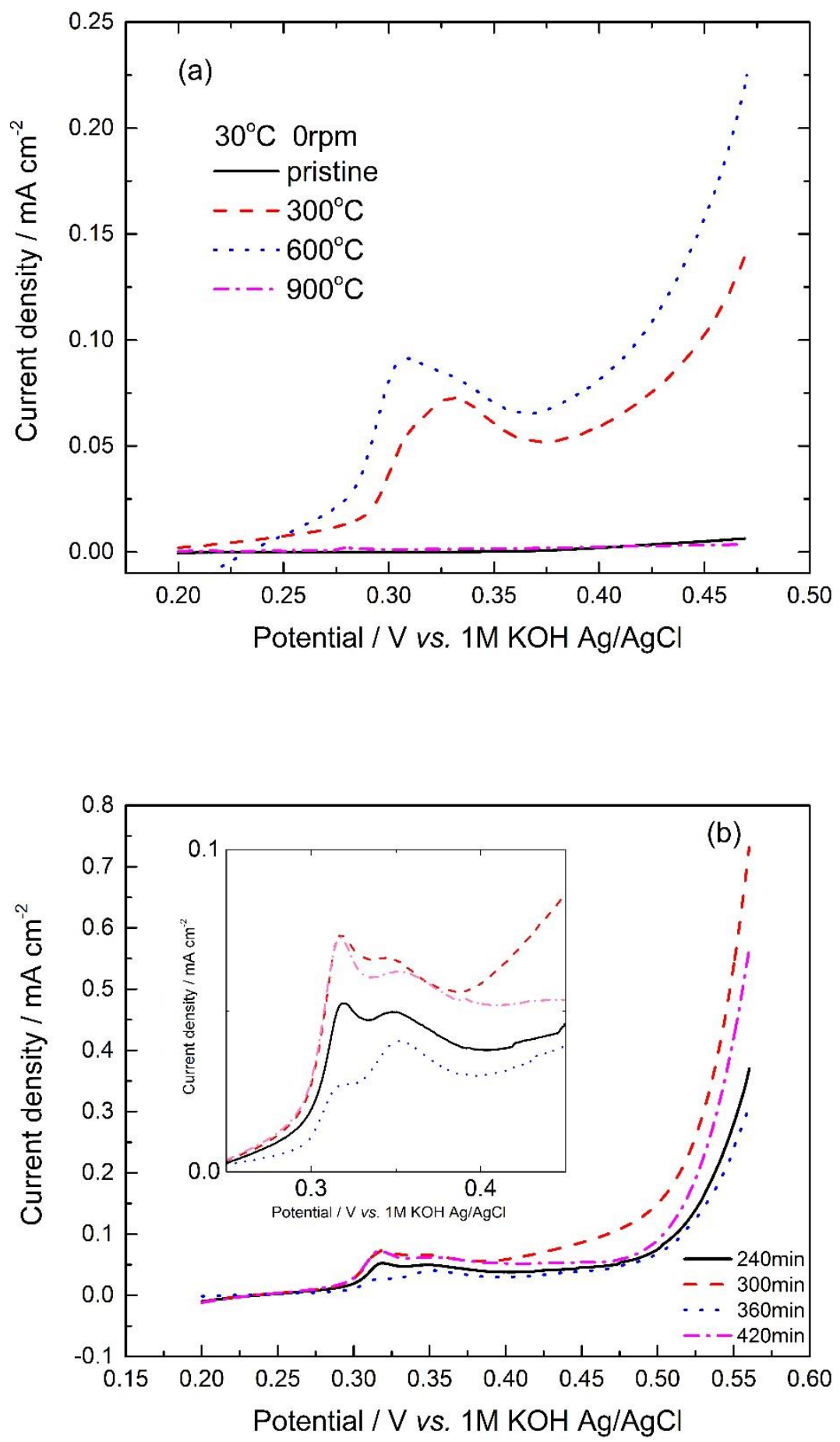

Figure.8 (a) LCV curves of OER measured at $0.5 \mathrm{mV} \mathrm{s}^{-1}$ in $1 \mathrm{~mol} \mathrm{~L}^{-1} \mathrm{KOH}$ for Ni-Co-Mn oxides heated at various temperatures for $150 \mathrm{~min}$, (b) heated at $600{ }^{\circ} \mathrm{C}$ for various time. 

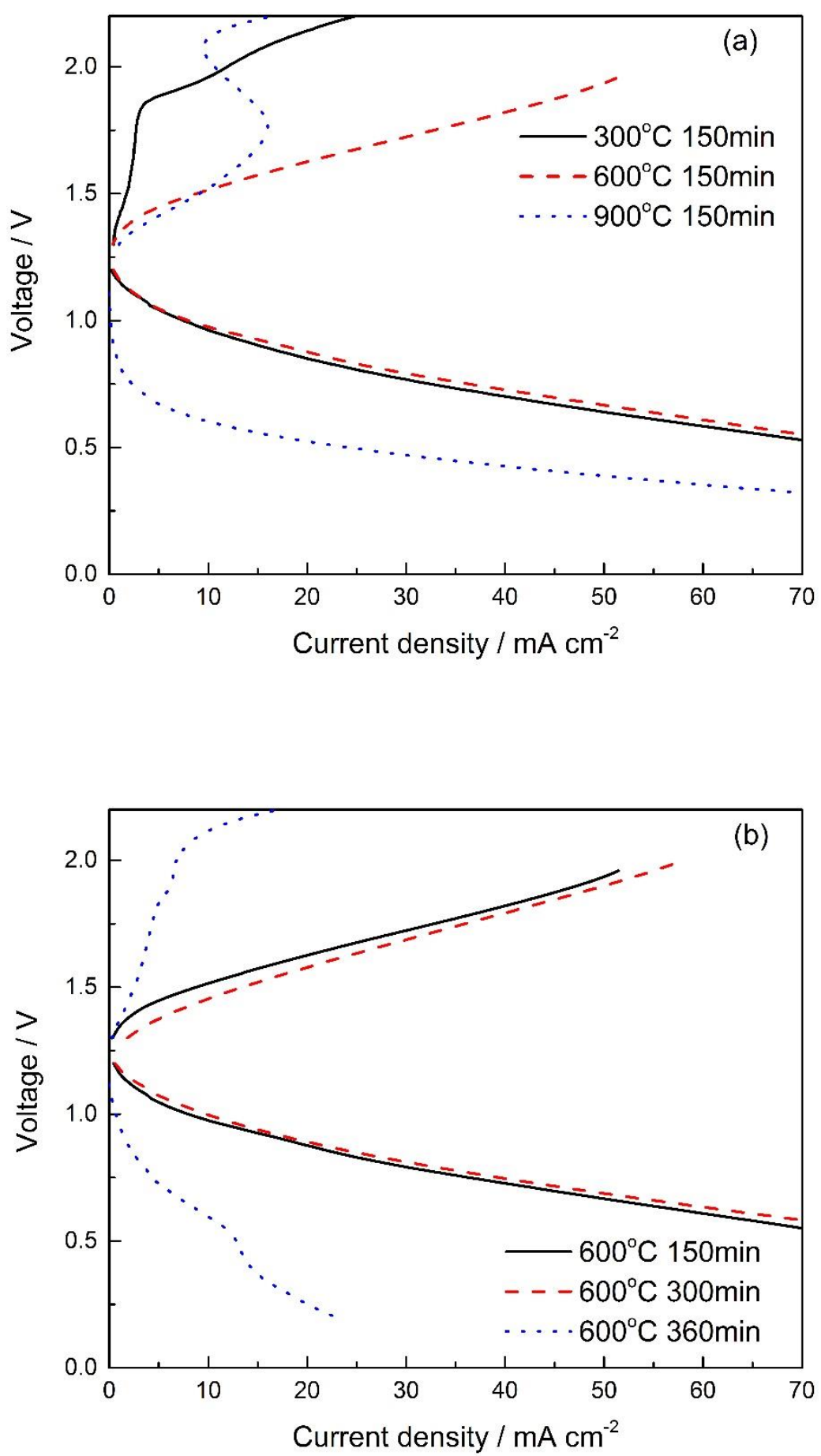

Figure.9 (a) Discharge and charge polarization curves and the power density against the discharge current density plot of zinc-air battery using Ni-Co-Mn oxides heated at various temperatures for $150 \mathrm{~min}$, (b) heated at $600^{\circ} \mathrm{C}$ for various time. 


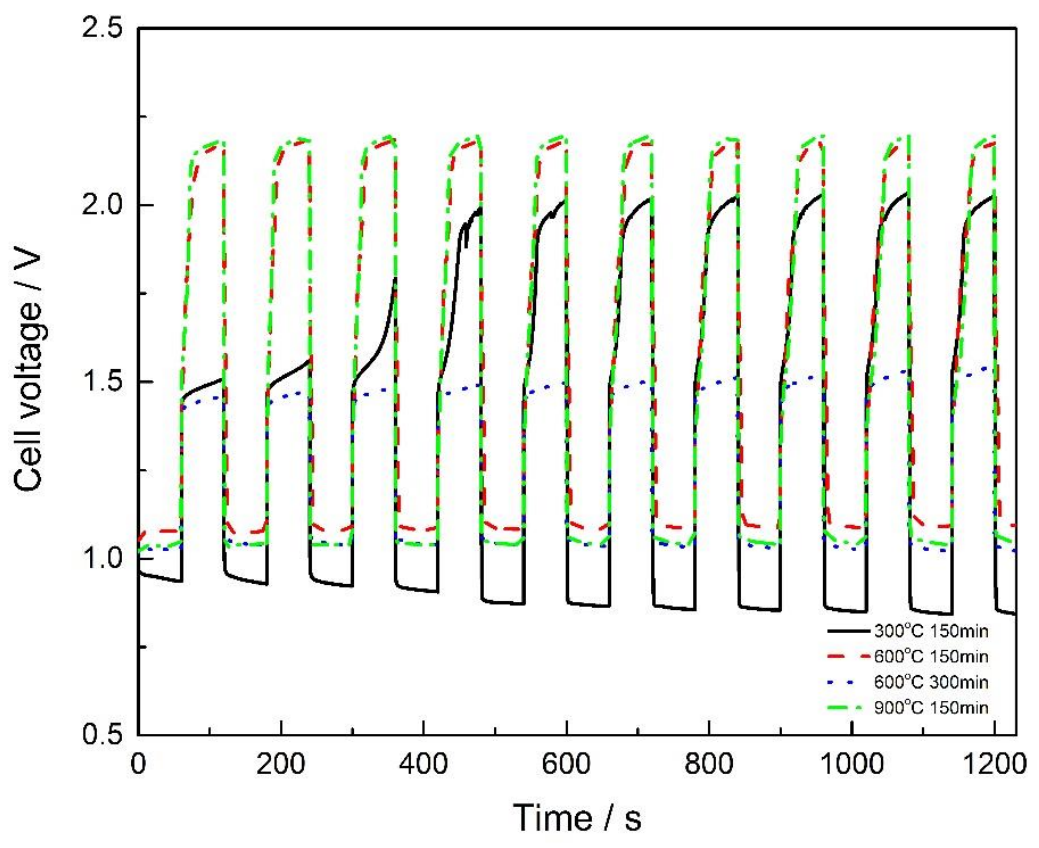

Figure.10 Charge-discharge-cycling curves at $10 \mathrm{~mA} \mathrm{~cm}^{-2}$ of zinc-battery using Ni-Co-Mn oxides renovated through various heat-treatment.

Table. 1 The metal ingredient content of the cathode materials.

\begin{tabular}{cc}
\hline Metal elements & Contents / wt \% \\
\hline $\mathrm{Co}$ & 9.20 \\
$\mathrm{Ni}$ & 57.85 \\
$\mathrm{Mn}$ & 0.12 \\
$\mathrm{Fe}$ & $<0.01$ \\
$\mathrm{Ca}$ & $<0.01$ \\
\hline
\end{tabular}

Table. 2 Properties of Ni-Co-Mn oxides heated at various temperatures for $150 \mathrm{~min}$.

\begin{tabular}{|c|c|c|c|c|}
\hline Treatment Temperature $/{ }^{\circ} \mathrm{C}$ & pristine & 300 & 600 & 900 \\
\hline $\begin{array}{l}\text { Electrical conductivity / } \\
\qquad \mathrm{mS} \mathrm{mm} \mathbf{~ m}^{-1}\end{array}$ & 0.0105 & 0.0119 & 0.1900 & 0.0066 \\
\hline $\begin{array}{l}\text { Apparent activation energies } \\
\text { at } \boldsymbol{\eta}=\mathbf{2 5 0} \mathbf{~ m V} / \mathrm{kJ} \mathrm{mol}^{-1}\end{array}$ & 49.20 & 38.73 & 8.47 & 42.16 \\
\hline
\end{tabular}


Table. 3 Properties of Ni-Co-Mn oxides heated at $600{ }^{\circ} \mathrm{C}$ for various time.

\begin{tabular}{|c|c|c|c|c|c|c|}
\hline Time / min & 60 & 120 & 240 & 300 & 360 & 420 \\
\hline $\begin{array}{l}\text { Electric conductivity / } \\
\qquad \mathrm{mS} \mathrm{mm} \mathbf{~ m}^{-1}\end{array}$ & 0.0001 & 0.0003 & 0.1200 & 0.2200 & 0.2200 & 0.2300 \\
\hline $\begin{array}{l}\text { Apparent activation } \\
\text { energies at } \boldsymbol{\eta}=\mathbf{2 5 0} \mathrm{mV} \\
\qquad / \mathrm{kJ} \mathrm{mol}^{-1}\end{array}$ & - & - & 4.86 & 4.34 & 5.37 & 5.58 \\
\hline
\end{tabular}

